\title{
On the "Truthiness" of Remixing the Classroom: A Reply to Randall Allsup
}

\author{
David J. Elliott \\ New York University, New York, USA
}

\author{
Marissa Silverman \\ Montclair State University, New Jersey, USA
}

The praxial philosophy of music education in Music Matters (2015) argues that music educators should teach democratically, creatively, and ethically toward empowering students' abilities to achieve full human flourishing through critically reflective music making and listening of all kinds. Moreover, Music Matters contends that teachers have a civic responsibility to develop students' awareness of why and how they should engage in music making for self- and community transformation. Thus, praxial music teachers resist all forms of oppression and defend pupils against their own personal influence. Also, toward the growth of pre-service and in-service music teachers' creative and educational abilities, Music Matters provides multidimensional, porous, and open concepts of musics, "educations," personhood, musical understanding, musical products, musical-emotional experiences, creativity, and curriculum. Therefore, our discussion refutes Randall Allsup's numerous misrepresentations of praxialism as an oppressive, uncreative, archaic, Master-apprentice, performance-centered philosophy that cultivates obedient students, and represents the worst abuses of "institutional" music teaching.

Keywords: praxial music education, praxis, eudaimonia, care ethics, artistic citizenship

I n 2005 the comedian and political satirist Stephen Colbert made an important contribution to public discourse when he coined the term "truthy." Truthy describes a statement that "sounds right" or "feels right"-especially when an authority figure says it repeatedly with intense emotion-even though it's false because it ignores or distorts relevant facts and/or deliberately omits portions of an author's view. Colbert explains that "truthiness" is not about truth; it's about opinions that have been crafted by a critic to deceive readers/listeners. Today,

(C) David J. Elliott and Marissa Silverman 2017. The content of this article is the sole responsibility of the author. The ACT Journal and the Mayday Group are not liable for any legal actions that may arise involving the article's content, including, but not limited to, copyright infringement. 
truthy statements go by other names: "fake news," "alternative facts," or "posttruth" rhetoric.

Truthiness pops up everywhere: in blogs, podcasts, TV news shows, social media and, sadly, in all domains of scholarship. In philosophy, a truthy statement is better known as a fallacy or a logical fallacy: an error in reasoning or a misleading argument that some critics use to convince their readers that they're correct about something in an author's book or article, even though there's lots of evidence to the contrary. There are approximately 300 types of logical fallacies. Perhaps this is why Colbert quips: "If a tree falls in the forest and no one hears it, I hope it lands on a philosophy professor."

\section{Introduction}

In Remixing the Classroom (or Remixing), Professor Randall Allsup offers a postmodern (or pomo) concept of school music education in the United States. Because other reviewers in this special issue of $A C T$ are likely to discuss many aspects of Remixing, we'll focus on analyzing and refuting many truthy claims he makes about the praxial philosophy of music education that we explain in the second edition of Music Matters (Elliott and Silverman 2015), hereafter MM2. We'll refer to the first edition (1995) as MM1.

In a nutshell, Allsup misrepresents our concept of praxialism as a hollow and harmful concept of music teaching and learning. We say "our" concept of praxial music education because Thomas Regelski (praxialism) and Wayne Bowman (practice theory) have contributed enormously during the last 20 years to the refinement of praxial visions of music education, the vast majority of which are aligned with MM2 and at odds with Remixing.

Our discussion unfolds in three parts. First, we examine several scholars' thoughts about critics' professional and ethical obligations to write accurate, fair, and balanced commentaries about authors' works. Second, we review several types of fallacious argument that permeate Remixing's critique of MM2. Following these sections, we refute Allsup's distortions of our praxial philosophy.

Elliott, David J., and Marissa Silverman. 2017. On the "truthiness" of Remixing the Classroom. Action, Criticism, and Theory for Music Education 16 (1): 124-67. doi:10.22176/act16.1.124 


\section{Characteristics of Trustworthy Philosophical Critique}

As Bowman and Ana Lucia Frega (2012) state, philosophical activity consists extensively in "questions, dialogues, and debate" (19). But what counts as reasonable and judicious philosophical discourse and criticism? What qualifies a "critical" debate as valid?

Critical commentaries must go beyond mere opinion. Philosophical critiques ought to be logically argued and carefully warranted. Moreover, as Mary Reichling (1996) emphasizes, readers and critics should keep an open mind while studying authors' arguments and avoid drawing hasty assumptions and conclusions about writers' intents. Critics have an ethical responsibility to make every effort to understand authors' viewpoints as they express them in their arguments and in relation to the complete context of their positions, including recent materials they've written that relate directly to their arguments.

Specifically, says Estelle Jorgensen (2006), philosophers should be "vitally concerned with the meaning of words because words are the vehicles for communicating ideas" (176). Thus, Bowman and Frega (2012) suggest that philosophical discourse "requires a delicate balance between tolerance and impatience ... between respect on the one hand, and on the other, contempt for things like dishonesty, deceit, and diversion" (italics added, 19).

Bennett Reimer (1996) adds that philosophical work should be "broadly based and audaciously managed" and "scrupulously honest in representing accurately and adequately the various views" under examination (60). Unfortunately, says Reimer (2003), it's often easier to represent a position as simpler than it is "by exaggerating a single, obvious aspect and ignoring its subtle, or shaded, aspects-by portraying a set of ideas at its extreme, stripped of nuance" (32). Critics who ignore these rudiments and ethics of reasoned and substantiated discourse jeopardize their claims in numerous ways, often by committing various types of fallacious argument.

In short, while everyone is entitled to their opinions, this doesn't mean everyone has an "epistemic right" to their opinions. To have an "epistemic right" to your opinions, you need to earn it by supporting it with evidence (Elliott and Silverman 2015, 30). As Daniel Patrick Moynihan says: "You are entitled to your opinion. But you are not entitled to your own facts" (cited in $M M 2,30$ ).

Elliott, David J., and Marissa Silverman. 2017. On the "truthiness" of Remixing the Classroom. Action, Criticism, and Theory for Music Education 16 (1): 124-67. doi:10.22176/act16.1.124 
With the views of Bowman, Jorgensen, and other scholars in mind, consider a few of Allsup's grounding claims. "As a performance educator, Elliott writes about student growth ... directed by the Master-performer and his earned expertise" (23). "For Elliott," and in the praxial philosophy, the student-performer's "technique, taste, and intuition are sensually conditioned (by a Master who teaches love, loyalty, and bondage). ... The learner comes to love the Law. The learner loves the Father" (31). Allsup hopes his readers will believe him when he claims that our praxial philosophy recommends a pedagogy that demands students' "loyalty" and aims to keep them in "bondage," which requires strict obedience to a "CEO-type director" or "performance Masters" (23).

Allsup's claims are false. They're just his opinions. He has no "epistemic right" to his opinions because he fails to provide evidence to support them. Moreover, the tone of his assertions and the words he chooses (for emotional and theatrical effect) to describe the contents of MM2-i.e., "bondage," "Masters," "Father," the "Law"-are sufficiently over-the-top that his critique sinks below the floor of accurate, fair, and balanced philosophical critique.

Now let's fact-check two major "post-truth" items in Remixing. First, neither edition of Music Matters (1995; 2015) mentions or advocates a Masterapprentice brand of pedagogy. Allsup's constant descriptions of MM2 as a draconian, Master-apprentice philosophy are false (just more opinions). So why does he keep chanting the claim that praxial music education is an undemocratic, uncreative, "Master-apprentice" philosophy/pedagogy? Because "Masterapprentice" is the cornerstone of Remixing's Big Fiction-Remixing's straw man attack (more on "straw manning" below)-that's meant to persuade readers that Allsup's dualism is true: the praxial approach to music education is dangerously totalitarian and Remixing is beneficent.

In fact, Music Matters advocates a democratic, reflective, creative, and ethically caring concept of music teaching and learning, as we'll substantiate in detail in the center of this article. For now, please read two groups of excerpts from $M M 2$ (below). As you read them, please consider whether Allsup is right or wrong when he claims that praxial music education centers on student growth directed by CEO-type directors (xii) who aim to "condition" student-performers' "technique, taste, and intuition" through "loyalty" to "Father"-figure teachers (31), and that MM2 says, "Music counts more than people" (Allsup, 100). And ask 
yourself whether he's accurate when he asserts that praxial music education focuses exclusively on teaching performing-that "Elliott" (Allsup's emphasis) doesn't discuss or support any other form of music making or creativity in either MM2 or MM1.

1. (a) MM2 argues that teachers should take a democratic, transformative, and charitable-educative stance toward students' empowerment and, therefore, reject simplistic and standardized teaching, CEO-type policy makers, and authoritarian teachers, as stated below.

Teaching and learning music for its transformative values requires that we rise above simplistic "aims" defined in terms of empirical measures of student performance. These paralyzing notions have nothing to do with education as a praxis-as a process of empowering people to achieve their musical and educational life goals through critically reflective doing, thinking, and flourishing. To achieve the latter, we must take a democratic and charitable-educative stance toward the people we serve, not the uncharitable stance many so-called educational policy makers (read: school-based accountants), CEOs, and authoritarian teachers take toward students [italics added]. (Elliott and Silverman 2015, 168)

(b) Praxial music education puts students' personal transformation and full human flourishing at the heart of its concerns. Like Bowman (2014) we argue that the best musical and educational practices are those that contribute to students' fullest thriving or what Aristotle called eudaimonia (e.g., Elliott and Silverman 2015, 43-53). Of course, there are many ethical and joyful forms of flourishing, none of which always follow automatically from specific musical engagements in what we call musical "praxes," a concept we explain later in our discussion of the natures and values of musics. Suffice it to say now that

[t]eaching and learning should center on human relationships and ideally promote positive transformations [italics added]. Students need and deserve teachers who have prepared thoughtfully and diligently in order to guide [not control] their musical, intellectual, emotional, ethical, and social thinking and doing. (Elliott and Silverman 2015, 34)

Earlier in the book we state:

Central to our concept of praxis is careful and caring thinking-and-doing for people's holistic development-musical, cognitive-emotional-somatic, social, cultural, ethical, and educational fulfillment and flourishing. (17)

Elliott, David J., and Marissa Silverman. 2017. On the "truthiness" of Remixing the Classroom. Action, Criticism, and Theory for Music Education 16 (1): 124-67. doi:10.22176/act16.1.124 
(c) Third, we argue strongly that

teachers have no right to think and do whatever they want in the classroom, let alone "oppress" or indoctrinate students with their own beliefs or the beliefs of any singular "expert." As the American educator Amos Bronson Alcott argues, the ethical educator "defends his pupils against his own personal influence. $\mathrm{He}$ inspires self-distrust." (cited in $M M 2,35$ )

(d) In Chapter 4-Education (107-152)-of MM2 we support our emphasis on person-centered, creative, and democratic education, and our opposition to oppressive pedagogies, by citing major themes in the works of Dewey (e.g., 1934, 1938), Freire (e.g., 1970), Noddings (e.g., 1992), and several other scholars. So, again, our praxial concept of education is person-centered. When Allsup claims that praxial music education rests on "overwhelming control" of students, he is wrong. And when he says that, "as a performance educator, Elliott writes about student growth and the appreciation of values, but for him, quality is measured and directed by the Master-performer and his earned expertise" (23), he is doubly wrong. (More evidence in the center of this article). Clearly, this is not how we conceive of growth or values, and we never say or suggest that "quality is measured and directed by the Master-performer."

Remixing fails to credit any of the arguments we've stated in sections (a) to (d) above. And it omits to mention any details in large sections of MM2 (such as our chapters on Personhood, 153-190, and Musical Values, 360-388) that oppose all forms of abusive teaching that attempt to dominate students (Allsup, 11) and, therefore, challenge Allsup's claims. By ignoring all this material in $M M 2$, Allsup commits the fallacy of slanting, which occurs when a critic accidently or intentionally omits pertinent material from an author's work to hide evidence that's important to the author's arguments. By omitting relevant material in MM2 Allsup denies readers the opportunity to make fair and balanced judgments about the content of our praxial philosophy. Such denials are forms of academic oppression.

Recall Reimer's (1996) admonition: philosophical work should be "broadly based and audaciously managed" and "scrupulously honest in representing accurately and adequately the various views" under examination (60). And recall what Bowman and Frega (2012) suggest: philosophical discourse "requires a delicate balance between tolerance and impatience ... between respect on the one hand, and on the other, contempt for things like dishonesty, deceit, and diver- 
sion" (italics added, 19). To this point, are Remixing's claims about praxialism fair, balanced, and truthful, or just truthy?

2. Another major element of Allsup's argument is that "Elliott" is a "performance educator" (Allsup, 23). In fact, David is not only "a performance educator." (By the way, what's wrong with being a good performer and a decent performance teacher like thousands of other music teachers past and present?) Since 1972 (David's first year as a secondary general music, band, and jazz ensemble teacher), he has continuously taught improvising, composing, and arranging in secondary schools and in university music-teacher education programs. This is why both editions of Music Matters (1995; 2015) devote several chapters to explaining (a) the natures and values of all forms of musical creativity, and (b) numerous creative teaching strategies-not "historically coded practices" or a total insistence on "excellence" (Allsup, xii)-that school music teachers may want to use as they guide and empower-not dominate-students' creative development toward life-long amateuring (e.g., Elliott and Silverman 2015, 412, 42740). Later in this discussion we'll provide more evidence to substantiate the importance of creativity in MM2. This evidence includes students' descriptions of David's composition courses.

So where is the evil Master performance-teacher in $M M 2$, and where is praxialism's alleged insistence on mastery at the expense of risk-taking? Nowhere, because praxial music education never says such things. And what evidence does Allsup provide to back up his claim that David and/or our praxial philosophy "recommends that all classes in music become classes in the practice and performance of music" (Allsup 2010, 56)? He provides none. Neither edition of Music Matters makes this claim.

So even at this early point in our response to Allsup, it seems fair to suggest that his accusations are merely his opinions. Which reminds us of what the "Dude" says in the cult movie "The Big Lebowski": "Yeah, well, you know, that's just, like, your opinion, man."

From one perspective, Allsup's misleading opinions about the praxial philosophy aren't surprising because many people in the pomo world see little reason (pun intended) for fact-checking (Wisnewski 2010, 244).

Elliott, David J., and Marissa Silverman. 2017. On the "truthiness" of Remixing the Classroom. Action, Criticism, and Theory for Music Education 16 (1): 124-67. doi:10.22176/act16.1.124 


\section{Fallacious Arguments}

As Remixing illustrates, some critics construct commentaries by using many logical fallacies for the purpose of spreading disinformation about authors' works. Just as a reminder, the straw man fallacy-which grounds Allsup's grand fable about praxialism-occurs when a critic deliberately ignores parts or all of what an author says in a book or article, and then substitutes a distorted and/or unsubstantiated version of what the author states. The critic creates the illusion that he's refuting the author's argument when, in fact, he's refuting his own truthy argument. Why engage in "straw-manning"? Because it's much easier for a critic to discredit his fictional version of an author's argument than to develop a fair, accurate, verifiable, and balanced critique of an author's real position. In Remixing, the straw man fallacy takes this form:

1. Elliott's and Silverman's praxial philosophy in MM2 says X

2. Allsup says $\mathrm{Y}$, a misrepresentation of $\mathrm{X}$

3. Allsup refutes $Y$

4. Result: Some of Allsup's readers will believe Allsup's refutation of Y and erroneously mistake it for a valid refutation of $\mathrm{X}$

"Straw-manning" usually involves other forms of fallacious argument such as slanting (see above). Here's another one often found in Remixing: the ad hominem-guilt by association fallacy. This form of fallacious argument occurs when a critic (e.g., Allsup) condemns an author's argument (e.g., praxial music education) by attacking the character or an alleged attribute of the author (e.g., "Elliott" is just a performance educator who demands student's obedience to the "Law"), and/or a group that's allegedly associated with the author (e.g., CEO-type ensemble directors), rather than critiquing the substance of the author's argument.

Allsup uses this type of ad hominum argument to create a fake equation: Elliott is "a performance educator" (23), which means that Elliott is "a CEO-type director or performance Master who envisions his job as the upholder of historically coded practices" (Allsup xii), which means that Elliott and praxial music education represent the worst of "institutional music education" in the United States. Allsup's use of the ad hominem fallacy gives him a way to concoct his truthy, straw man proposition, which he hopes readers will accept:

Elliott, David J., and Marissa Silverman. 2017. On the "truthiness" of Remixing the Classroom. Action, Criticism, and Theory for Music Education 16 (1): 124-67. doi:10.22176/act16.1.124 
Elliott = "performance Master" = "a CEO-type director" = "institutional music education" = "the pedagogy of closed forms" = the "worst excesses of public school reform" = praxial music education (Allsup, xii).

Allsup's claims about and interpretations of our praxial philosophy are not only wildly fictitious, but they leave us in desperate need of a post-postmodern chuckle. For example, Remixing's continuous bashing of Music Matters unfolds like a sequel to Rogue One: A Star Wars History. In such a sequel, we might see Allsup helping the rebel heroine, Jyn Erso, blow up Stormtroopers (e.g., CEOtype directors or "performance Masters") of the Galactic Empire, which, of course, are aligned with Mr. and Mrs. Darth Vader: i.e., Elliott and Silverman. Welcome to the "Dark Side" of music education philosophy!

Ironically, Allsup insists that Remixing is "open" and that our praxial philosophy is closed-uncreative, undemocratic, tyrannical. Not only is this truthy, but when we peel away his false assertions, we see a few points of overlap between what MM2 (2015) says and what Remixing (2016) says. For example, we agree with his concerns about the limitations and abuses of narrow "institutional music education," which the premises, themes, and full content of $M M 2$ also challenge strongly.

In addition, we agree with Allsup's support of music education as a force for developing civic-minded public intellectuals (Allsup, 110) who, among other things, resist the oppressions of neoliberalism. However, the idea that teachers should only support the growth of students as "intellectual" leaders puts too much emphasis on "talk-talk-talk" about social justice, instead of empowering students to create concrete examples of and actions for social justice through all forms of musicing. In fact, David has written for many years $(2007,2012,2014)$ about the need to conceive and practice music education in ways that ignite and guide students' active "artivism" or what we also call (in MM2 and elsewhere) "artistic citizenship" (Elliott and Silverman 2015; Elliott, Silverman, and Bowman 2016): i.e., music making by people (young and old, and students at several levels) for all kinds of grass-roots social transformation.

Allsup doesn't acknowledge the possibility that MM2 and Remixing have shared concerns because (it seems to us) he hasn't read $M M 2$ completely and carefully, let alone given readers a fair and accurate report of its key points. Indeed, while Remixing is a contribution to the longstanding and evolving litera- 
ture of music education philosophy, it's so busy "muddling" its stories about praxial music education that it's difficult for readers to discern more opportunities for agreements between praxialism and Allsup's postmodernism, or recognize where such border-crossings would be injudicious. In fact, there are several points in Remixing where Allsup says what we say in MM2. For example, when we offer concepts of the natures, values, and limitations of musical "traditions," and the injurious nature of educational power structures and "codes" (etc.), Allsup scorns them. But when he makes the same points, and uses some of the same words we do, it's perfectly fine.

We'll end this section of our article with an important observation about Allsup's frequent references to "Elliott's philosophy of 'praxial' music education," by which he means the first edition (Elliott 1995) of Music Matters. By referring so many times to the first edition and largely ignoring the second edition (2015), Allsup commits the fallacy of false attribution. This occurs when a critic attempts to mislead his audience by referring to an author's outdated argument-thereby hiding material in the author's current, definitive argument-to support his/her criticisms.

Because $M M 1$ is, as of this writing, 22 years old, it's not a completely accurate source of information about our praxial philosophy of music education, which is why we wrote the second edition (2015), and which is why $M M 2$ is, in many ways, a new book. As we explain elsewhere (Elliott and Silverman 2015b):

The process of planning and writing $M M 2$ began with rethinking and "revisioning" the first edition of Music Matters (1995), or MM1, which included (1) clarifying, updating, and expanding on the premises and themes in $M M 1$ and (2) studying (about 900 sources), and then selecting and integrating what we considered the most logical, valid, and evidenced-based research [see our selected bibliography: http://www.musicmatters2.com/bibliography/] in a wide range of fields, including the philosophy of music, mind, and personhood; music psychology, ethnomusicology, neuroscience, and emotion studies; the sociology of music; creativity studies; and educational philosophy. (107)

Part of this re-visioning process was made possible thanks to the verbal feedback and emails we've received from hundreds of school music educators, graduate students, professors, and community music facilitators worldwide.

Consequently, as we said, the authoritative version of our praxial philosophy is the second edition, which offers: completely new chapters on the natures and values of education, personhood, musical emotions, and applications of all these 
concepts to school and community music (CM); broader and deeper concepts of the natures and values of musical understanding ("musicianship + listenership") and musical "products" (e.g., improvisations, compositions, musicaltechnological musicing, etc.); updated explanations of the natures and values of musicing (i.e., performing, improvising, composing, arranging, leading, digitalaudio musicing, etc.); discussions of presentational, participatory, and three other forms of musicing as explained and recently updated by Turino (2008, 2016); and our concept of artistic citizenship (or "artivism") for social justice (e.g., Elliott and Silverman, 268-70, 375-7).

It's important to emphasize that the first edition of Music Matters (1995) is often Allsup's main source of anti-praxial claims and cherry-picked "evidence." Accordingly, he often gives the false impression that both editions say the same thing, which gives him a way of avoiding a great deal of material in MM2 that undercuts his false assertions. And by downplaying $M M 2$, he marginalizes Marissa's role as the co-author of MM2. To clarify, Marissa participated fully and equally in the authorship of the book. Her professional qualifications, her personal secondary school teaching experiences, her feminist perspectives on "educations," her many publications and personal research interests and, because she is a Jewish woman, the anti-Semitism she suffered throughout her public school and university education on Long Island and at NYU-all of these factors made a huge difference in shaping the book's praxial priorities and content.

For all of the above reasons, Peter Webster (2015) says:

Nearly twenty years ago, music education philosophy changed forever with the publication of Music Matters [1995]. The second edition [Elliott and Silverman 2015] is a sweepingly new and expanded text that rises to an unprecedented level of sophistication... (see $M M 2$, back of the book)

"Sweepingly new and expanded." So, again, whenever Allsup refers to the first edition of Music Matters to make an argument about our praxial philosophy, he is committing the fallacy of false attribution.

Of course, many postmodernist commentaries like Remixing argue that philosophical fallacies are simply irrelevant; that philosophical guidelines for argumentation are just the means by which privileged elitists try to maintain their positions of power; and that logic is just a clever technique that some Father 
figures (Allsup's capitalization) use to make up bedtime stories about the world that are intended to oppress us.

Unfortunately, as educational philosophers Nicholas Burbules and Rupert Berk (1999) remind us, fallacious arguments limit freedom of thought and honest debate; they create unequal power relationships; they divide authors and philosophies into opposing camps and, therefore, they promote closed-minded attitudes that cut off possibilities for compromise and the growth of an entire realm of scholarship (34). Indeed, instead of opening doors and building bridges, Remixing's closed-minded stance toward our praxial philosophy erects walls. Allsup doesn't have one legitimate thing to say about either edition of Music Matters. This closed-mindedness runs counter to his allegedly "open" philosophy.

So in the end, the ultimate "victim" of a truthy critique like Allsup's is not a book like Music Matters, or a philosophy like praxial music education, or a person like "Elliott." It's something much larger and much more important: the integrity, vitality, and value of an entire domain of reasonable, logical, and evidence-based scholarship like music education philosophy.

\section{Musics}

Allsup's failure to proffer a "definition" of music, let alone a comprehensive concept of what music is or might be (13), is a huge hole in his philosophy. Surely a "philosophy of music education," which is in the title of his book, requires (at the very least) a basic idea of what music might be. Otherwise, how can any school music teacher or graduate music education student develop a reasonable concept of anything "musical," including musical understanding, musical emotions, musical expression, musical creativity, music teaching and learning, and so on. Given this major gap in Remixing, we're "unseduced" (Allsup's term) by his unwillingness to try "muddling" his way through a wide range of intricate aspects of the natures and values of musics. Thus, we can only conclude that Remixing is so "open"-empty of a deep and broad concept of music-that "anything goes." If so, then nothing goes. Good luck with that, especially if you're just beginning your teaching career, or if you're an experienced teacher who can't afford to "muddle" his/her way out of teaching and advocating wisely for "music" education and navigating today's neoliberal music assessment standards, and so on.

Elliott, David J., and Marissa Silverman. 2017. On the "truthiness" of Remixing the Classroom. Action, Criticism, and Theory for Music Education 16 (1): 124-67. doi:10.22176/act16.1.124 
Since Allsup declines to suggest any reasonable concept of music-let alone offer a multidimensional concept of music-we'll summarize our praxial concept of musics, which we describe as a provisional, porous, and protean concept of musics as diverse social praxes-not practices. We say "not" practices-not because we disagree with Bowman's concept of musical practices-but only because (in our view) a practice can be ethical or unethical, whereas a praxis is, from Aristotle's perspective, an ethical pursuit guided by what he calls "phronesis" or practical reasoning. Phronesis helps us make wise and ethical choiceswith and for our students, not just for them, as Allsup claims-about a host of issues that arise in short- and long-term musicing and music teaching and learning. So praxial music education urges teachers and students to engage together toward developing the abilities to make practical judgments, decisions, and choices about all forms of students' musicing, listening, and interpersonal relationships-before, during, and after their musical involvements.

MM2 emphasizes from the get-go that there's no such thing as "music"; instead, there are "musics." Music is not a unitary phenomenon, and music is not a thing or "sounds-works" alone. MM2 argues that each kind of music (e.g., American bebop jazz, or cool jazz, or jazz-rock fusion; urban blues; County Claire Irish fiddle music; Balinese kebyar; roots reggae, etc.) involves at least four open, "swirling," human dimensions, as described below, and as illustrated in the "circles diagrams" that follow.

1. Person(s), or "musical doers." Music makers and listeners of all ages, abilities, aims, and desires, as well as others who may listen while participating with music makers as (say) dancers, worshippers, recording engineers, and people who have important musical "support roles" such as stage hands, sound technicians, rock-band "roadies," musical theater and opera set designers, and lighting directors.

2. Musical processes or "doings." These emerge from and depend on the specific characteristics of each kind of musical understanding that propels people's processes of musicing and listening, musical experiencing and responding (emotionally, cognitively, bodily, etc.), musical valuing and evaluating (e.g., music "critiquing"), and so on.

3. Musical products or "outcomes." In the widest possible sense of this term, these outcomes emerge from people's musical understandings and are deemed 
valuable in specific musical situations. Importantly, in real time, musical doers, processes, and products are unified. And musical processes-products can include all types of music making and listening.

4. Musical contexts. By this we mean all possible musical spaces and places: e.g., classrooms and community settings; social, historical, political, economic, gendered, architectural, and other situations; and settings in which musics were or are being made by students, amateurs, and professional music makers. All these factors have a profound impact on the natures of musics as they're conceived and applied in specific praxes, and on how they undergo minor or radical changes.

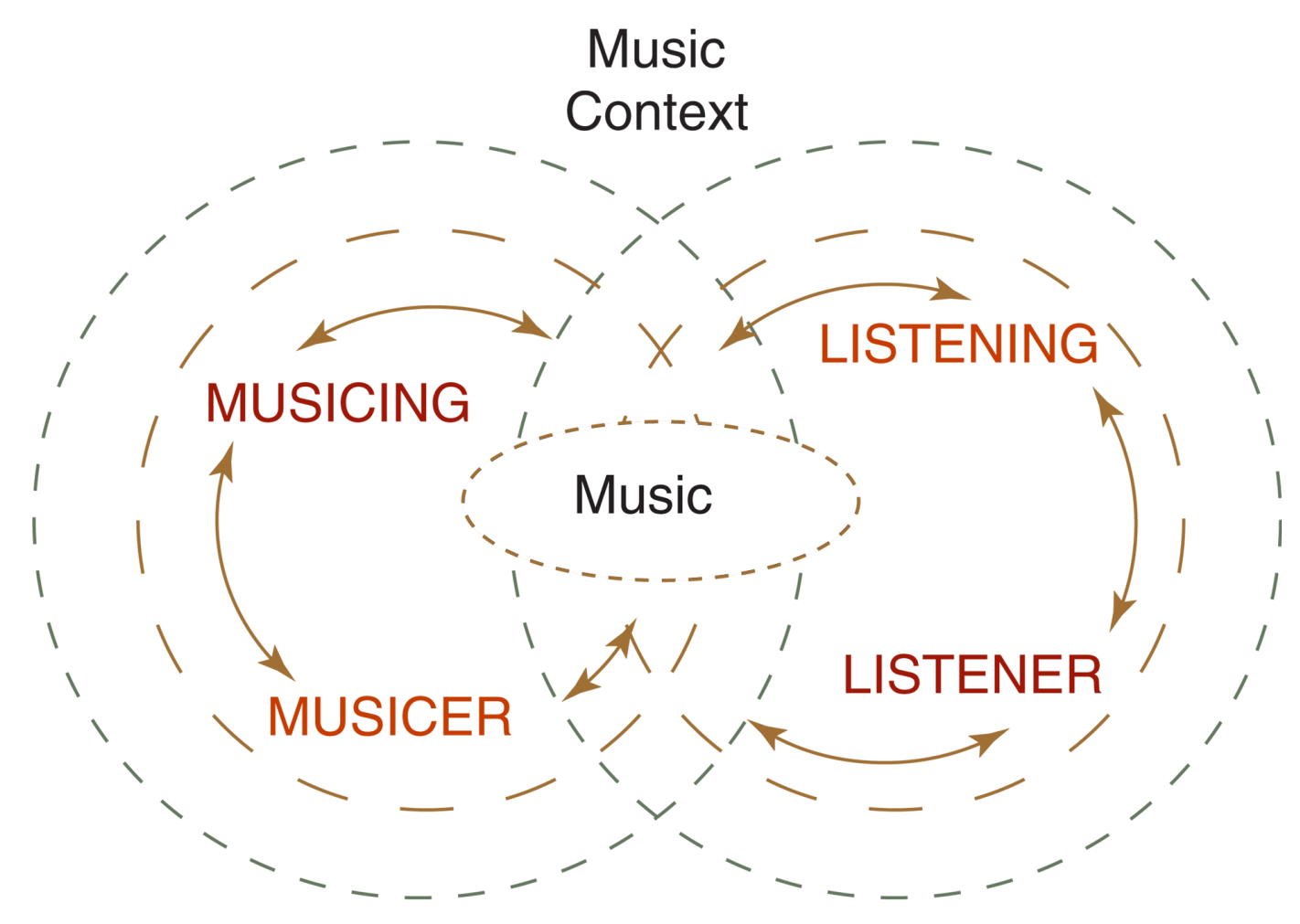

Elliott, David J., and Marissa Silverman. 2017. On the "truthiness" of Remixing the Classroom. Action, Criticism, and Theory for Music Education 16 (1): 124-67. doi:10.22176/act16.1.124 


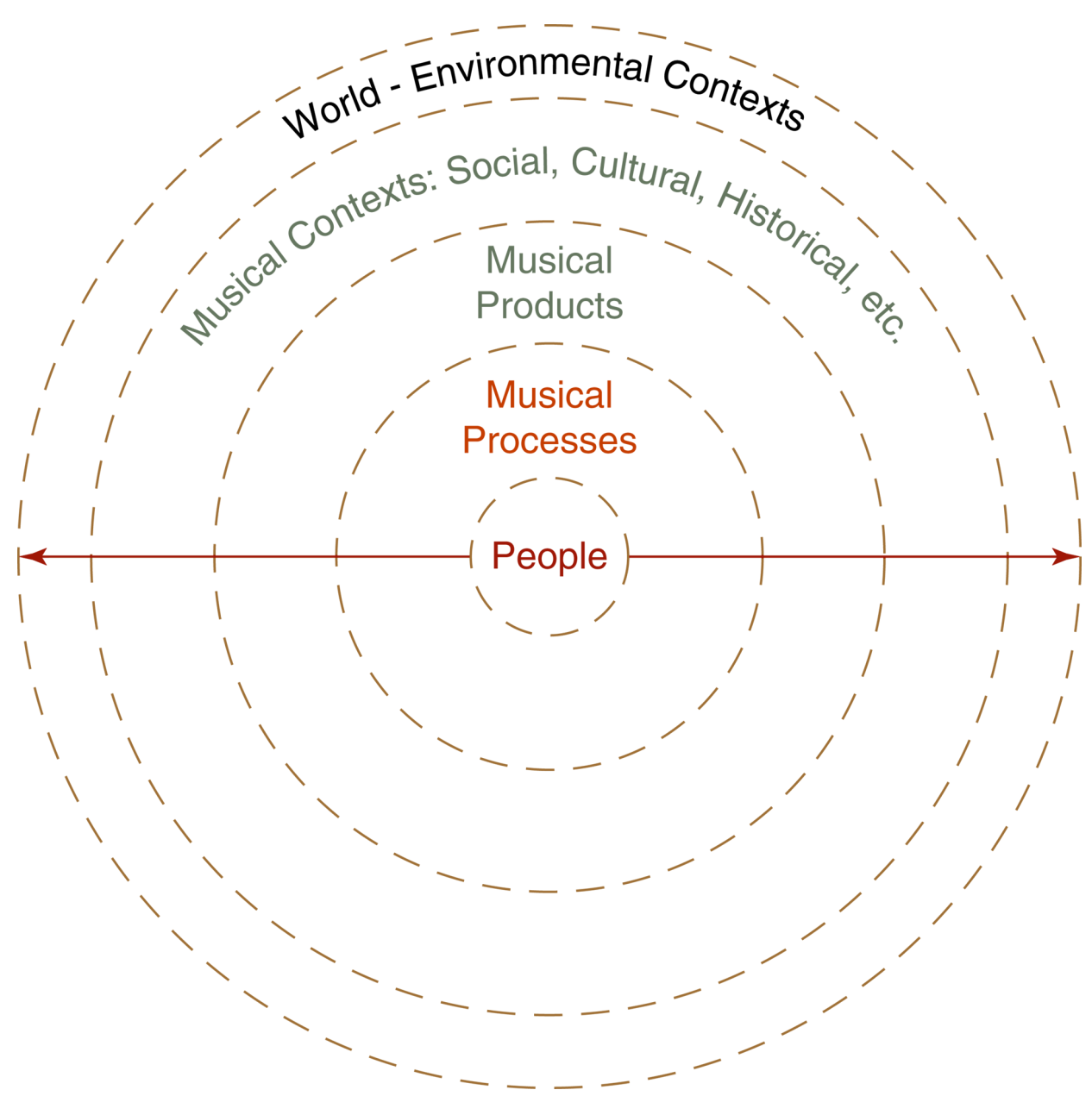

At first glance, the first diagram above seems to put "music" at the center; however, examined closely, readers will see that musical products (center) come into being and are experienced in virtue of one or more "musicers." So, in fact, music makers of all kinds, and listeners, are the starting points for the creation and experience of each kind of music (e.g., making and listening to American bebop jazz, or cool jazz, or jazz-rock fusion; urban blues; traditional County Claire Irish fiddle music; Balinese kebyar; roots reggae, etc.). And each dimension depends on all other dynamic dimensions "at work" among porous, softly-bounded musical-social-cultural contexts, as indicated by the dashes in the diagrams above. We place the first and second (specifically people-centered) Action, Criticism, and Theory for Music Education 16 (1): 124-67. doi:10.22176/act16.1.124 
diagrams together in $M M 2$ (101) to clarify all of the above. This "two-circles" concept isn't meant to account for all possible themes and interactions of the praxial concept of musics in $M M 2$, only major "launching" themes.

It's important to emphasize that, in real-time human-musical experiences, all details of all four dimensions described above are simultaneously dynamic, interactive, permeable, and fluid in their social-cultural spaces and places. Yes, there are musical practices that are racist, homophobic, and so forth. But in our vocabulary, these are practices in the worst sense-just as torture is a "practice"; they're not ethically guided praxes that aim for ethically "right" (humanistic) results, including individual and community growth, joy, mutual respect, continuous evolution, and all other dimensions of eudaimonia.

So is Allsup being fair and reasonable when he argues that MM2's concept of music is completely "norm-governed," "coded," "closed," and "dependent on context" alone? We suggest that there's sufficient evidence, even in this short discussion of our concept of musics, that Allsup doesn't give his readers a fair and accurate interpretation of our multifaceted, flexible, and open concept of musics.

\section{Praxial Music Education: A "Terribly Old" Philosophy?}

Allsup (2016) claims that

Elliott positioned his praxial philosophy [1995] as a new philosophy of music education, but it is actually terribly old. Conserving a method that Western music educators have been practicing for centuries, he merely changed the rationale for why we teach and learn in closed forms ... without proposing a new method of teaching in return, Elliott merely substituted late-twentieth-century multicultural codes for those universalist tropes that were still haunting the university (and that had found material affect in public-school music programs). (31-2)

Are Allsup's assertions factual, trustworthy, and balanced? Since he's referring to $M M 1$, we'll go back to that edition to make a few points.

The first edition was "new" in many ways. First, it offered a clear alternative to the longstanding philosophy of music education as aesthetic education (Reimer 1970, 1989) that privileged aesthetic objects rather than people. And Reimer (1989) opposed the teaching of popular musics, whereas $M M 1$ endorsed the values of rock (193-4), rap (204), and other popular styles that were previously off-limits in most discussions of music education at the time.

Elliott, David J., and Marissa Silverman. 2017. On the "truthiness" of Remixing the Classroom. Action, Criticism, and Theory for Music Education 16 (1): 124-67. doi:10.22176/act16.1.124 
Comparing the aesthetic education philosophy with the praxial philosophy (1995), McCarthy (2000) argues that "at no other time in our professional history did we have a view of music education that is as people-focused," meaning that praxial music education operates as "a social collective" based on "ongoing dialogue between teacher and student" to develop "individual creativity in the context of a shared communal practice" $(3,5)$. Clearly, McCarthy doesn't think David's "new" philosophy was "terribly old." Numerous other scholars concur for various reasons (e.g., Regelski 2005; Barrett 2007).

Moreover, $M M 1$ states that all forms of music making are inherently valuable: "Performing, improvising, composing, arranging, conducting-all are worth doing for the doing itself, meaning 'for the sake of the self,' for the values of selfgrowth, self-esteem, and other values" (121). Additionally, "all forms of musicing are mutually reinforcing and interdependent from a social, artistic, ethical, and educational point of view" (172). Importantly, MM1 says that music listening ought to be taught and learned in conjunction with music making (175), and that teachers should also develop students' listening abilities systematically via recordings and in relation to "performance projects, composition projects, arranging projects, and conducting projects" (156-7).

Allsup fails to mention any of these pertinent points-thereby committing the fallacy of slanting again-which undercut his criticisms of praxial music education as being "very old," performance-centered, uncreative, and so forth.

Before moving on, it's important to highlight a methodological feature of MM1's starting point, which, in 1995, marked a paradigm shift. This is partly what Webster is referring to when he says that "[n]early twenty years ago, music education philosophy changed forever with the publication of Music Matters [1995]." That is, as we say elsewhere (Silverman, Davis, and Elliott 2014), by beginning with the concept that "music is a human activity" (Elliott 1995, 39-45), MM1 broke with past music education philosophy, which operated in a top-down, synoptic manner. That is,

the longstanding philosophy of "music education as aesthetic education" [Reimer 1970, 1989] ... begins with the assumption that the nature and value of music and music education are best explained in terms of $19^{\text {th }}$-century aesthetic theory generally, and Susanne Langer's aesthetic cognitivism particularly. (56)

Elliott, David J., and Marissa Silverman. 2017. On the "truthiness" of Remixing the Classroom. Action, Criticism, and Theory for Music Education 16 (1): 124-67. doi:10.22176/act16.1.124 
The paradigm shift in $M M 1$ is twofold: (a) praxial music education rejected aesthetic education's philosophical "method" of simply downloading the theories of Langer and Meyer to explain the nature and values of music and its concomitant faith in Enlightenment notions of music; and (b) $M M 1$ followed a pragmatic, person-centered route to conceptualizing music by starting with the basic premise that "music is a human activity" (Elliott 1995, 39-45). From this launching pad, David developed concepts of musicing, musical products, musical understanding (etc.) by probing the relationships between musics and everyday, social-cultural musical actions and experiences. These processes led to the concept of music curricula as "reflective musical practicums," which was new at the time. This approach to teaching-which is not a "method" but an open, educative process-pivots on all forms of musicing and listening in small and/or large musical practicums that emphasize democratic and constructivist teaching strategies: e.g., students' individual, cooperative, and progressive musical problem solving, problem reduction, problem finding, listening logs, peer-teaching, and teachers' deliberate "fading" to the classroom sidelines (Elliott 1995, 26990). All these facets of praxial music education, and many more, are updated and expanded in $M M 2$.

Please review Allsup's assertions, above, and consider whether they're accurate, fair, and balanced. Is Remixing accurate when it says that $M M 1$ was just what "Western music educators have been practicing for centuries" (Allsup, 312)? And does it seem reasonable to say that David didn't propose a new way of teaching? We don't think so.

Now let's turn to the natures and values of creativity, another dimension of praxialism (Elliott 1995) that was reasonably new at the time and went far beyond what Allsup describes as "a method that Western music educators have been practicing for centuries" (31).

Barrett (2007) emphasizes that "Elliott's concept of creativity goes far beyond traditional notions of creativity-as-composing to include all forms of music making: arranging, composing, conducting, improvising, and performing” (177). Numerous scholars agree (e.g., Burnard 2005; Campbell 2008; Goble 2003). $M M 1$ also argues that musicing should be taught side-by-side with moving and dancing whenever possible, moving and poetry, moving and drama, and so on

Elliott, David J., and Marissa Silverman. 2017. On the "truthiness" of Remixing the Classroom. Action, Criticism, and Theory for Music Education 16 (1): 124-67. doi:10.22176/act16.1.124 
$(129,248)$. All these aspects of praxial music education are updated and expanded in MM2.

When Allsup claims that MM1 is/was a "terribly old" view, and that David completely failed to "propose a new method of teaching," is he correct? Does he supply evidence for his claims? No.

Was/is David's pre- $M M 1$ and post- $M M 2$ teaching infused with praxial principles of teaching and learning composing, improvising, and arranging? Examine the following statements by three students who took David's composition and arranging courses between 1972 and 2016. First, Dr. Peter Hatch, who was David's general music student in 1972 at Newtonbrook Secondary School in Toronto. Second, Keith Loach, who was his undergraduate music education student in 1980 at the University of Toronto. Third, Alyssa Mendes, who was David's MA music education student in 2016 at NYU.

Compare what they say with Allsup's allegations, past and present, that David is just a performance teacher; that praxialism is only concerned with teaching performing; that our praxial philosophy is an uncreative and undemocratic philosophy; that it's based on an authoritarian, Master-apprentice pedagogy, and so on. Are these and Allsup's other assertions about David and the tenets of praxial philosophy (Elliott 1995; Elliott and Silverman 2015) accurate, rightful, and balanced?

1. David's approach to teaching composition in my high school general music class in 1972 heavily influenced me personally and, later, professionally. David's wide-ranging concepts about and many ways of teaching us how to compose in diverse styles, including the pop and rock styles in those days, inspired me to pursue a $\mathrm{PhD}$ in composition. His easy-going, enthusiastic, and cooperative learning-by-doing processes, and his emphasis on linking our composing to hearing our class and individual projects performed in class, and by members of the Newtonbrook S.S. band, choir, and chamber groups, has shaped my own work during my $30+$ years as a Professor of Composition at Wilfred Laurier University, Canada. (Peter Hatch, personal communication, April 10, 2017)

2. I was fortunate to have taken an undergraduate music education composing and arranging course with David in 1980 at the University of Toronto. David's approach to organizing and teaching the class was groundbreaking for me and my peers. The course involved creating compositions and arrangements for a variety of small groups in a variety of styles, which my classmates and I and David performed for each other, reworked, revised, and re-performed each week.

David encouraged us to explore and take chances while composing and arranging, and to avoid getting hung up on textbook theory or rules. From time to

Elliott, David J., and Marissa Silverman. 2017. On the "truthiness" of Remixing the Classroom. Action, Criticism, and Theory for Music Education 16 (1): 124-67. doi:10.22176/act16.1.124 
time, in the midst of composing and arranging, we took breaks to discuss practical ideas in two small books that we all had and used that offered melodic, harmonic, and arranging strategies that we could use to generate musical ideas, especially when "the muse" failed to visit.

Our class discussions, and David's constructive feedback with and for us, was always informal, open-minded, relaxed. At one point, each of us worked on arranging a piece for the $\mathrm{U}$ of $\mathrm{T}$ jazz ensemble, which David led at the time. I chose the old standard Some Day My Prince Will Come. The experience of taking my creation (which David didn't formally "grade") from concept to hearing its performance by the big band jazz ensemble was thrilling, not to mention incredibly educational. (Keith Loach, personal communication, April 4, 2017)

3. The MA course I took in 2016 with Dr. Elliott at NYU, which was called "Teaching Composition in Middle and Secondary Schools," taught us how to compose and improvise-and, at the same time, how to teach composition and improvisation-in different styles, including many forms of "soundscapes," free improvising, electronic styles, 12-tone music, different types of contemporary song writing (e.g., pop, rock, hip-hop), blues improvising, etc. After moving through these styles, we back-tracked to create new compositions by interweaving different aspects of the compositional styles we'd learned the first time to create cross-over pieces. Listening to examples of past and current composers' pieces and improvisations in the various styles we learned was really inspiring, and it gave us more ideas for creating short film scores.

Sharing, reflecting, collaborating, and a lot of good-times were at the heart of every class. I always looked forward to our classes, and I loved hearing my pieces performed by my peers. Because of the course, I'm now teaching my high school students to compose and improvise. I never thought I'd be able to do it, let alone feel comfortable teaching composition. (Alyssa Mendes, personal communication, March 25, 2017)

The fact is that MM1 is both a practice-based and a conceptual philosophy, as is MM2. MM1 is rooted in David's early music making and teaching, as well as what he's done in these areas since 1965. His composing began from what he learned and observed during workshops in 1965 with celebrated Canadian composers like R. Murray Schafer who wrote the groundbreaking book The Composer in the Classroom (1965). David was in that classroom. Again, compare what we've explained and documented in the preceding sections of this article with Allsup's claims about praxialism being a performance-based and CEO-directed pedagogy, which demands students' "loyalty" and obedience, and a "terribly old" and closed concept of music education that pivots on "historically coded practices" and an insistence on "excellence." Are these and many other anti-praxial assertions in Remixing reasonable and philosophically warranted? Are Remixing's claims about our praxial philosophy factual, trustworthy, and even-handed, 
"broadly based and audaciously managed," and "scrupulously honest" (Reimer 1996, 60)? We don’t think so.

\section{Traditions and Standards}

Allsup distorts our concepts of musical traditions and standards. He misrepresents our perspectives on these aspects of musical praxes by arguing that traditions and standards of practice are, in the ways we examine them, closed, rigid, and oppressive. His interpretations of $M M 2$ are incorrect.

As we explain in $M M 2$, some traditions evolve slowly or quickly, some regress, and some die out. These processes depend on practitioners' commitments to preserving traditions, or modifying them to greater and lesser degrees, creating hybrid traditions, and/or responding (or not) to a wide range of social, cultural, economic, educational, political, gendered, and other variables that constantly impact music makers, musical processes, and their circumstances of living and musicing (e.g., 49-50, 229).

So in our praxial philosophy, traditions and standards of practice are not static or unitary "things"; they're living processes and networked subjectivities; and they're as different as the diverse musical praxes of which they're a part. In different musical praxes, some traditions and their associated "standards"meaning beliefs, "action ideals," values, principles, ethical judgments-are taken more seriously than others, and some are more contested than others. Musical praxes, and the natures of the traditions and standards they include, are always "in negotiation." Traditions take multiple forms, some of which are more open, complex, ethical, and flexible than others.

As Bowman (2012) says, "practices [and traditions] ... are, among other things: social in origin; social in execution; sources of communal or collective benefits; rooted in historical traditions that are interpreted differently (and sometimes in conflicting ways) by their practitioners; and reliant upon apprenticeship for their transmission" (17).

Standards, in our senses of the term (e.g., values, principles, ethical judgments, etc.), are important because, among other things, they activate students' and teachers' dialogues about the natures and values of musical processes and products, and they help students make important distinctions between and among all sorts of musical variables.

Elliott, David J., and Marissa Silverman. 2017. On the "truthiness" of Remixing the Classroom. Action, Criticism, and Theory for Music Education 16 (1): 124-67. doi:10.22176/act16.1.124 
Allsup creates a simplistic, hierarchical dualism: his "open," "unholy," and "muddled" view of "tradition" is good; our praxial concept of tradition is crippling, conservative, and suffocating because, among other things, it's based on fearsome "Laws." He is wrong.

Allsup's claims take no account of what we actually say about tradition(s) in $M M 2$, and he ignores the substantial philosophical literature-including praxial, pragmatic, and practice-theory philosophies of music education-that has emerged in the last 20 years to explain and refine teachers' understandings of the conceptual and practical significance of musical traditions, as we use the term in MM2.

As we explain in $M M 2$ (e.g., 49-50), Dewey viewed students' "initiation"synonyms for initiation include introduction, engagement, "welcoming" (as we use the term, Elliott and Silverman 2015)-into a living tradition of practice as "the means by which the powers of learners are released and directed" (Dewey 1974, 151). Released and directed, said Dewey, not restricted and controlled, which is how Allsup interprets Dewey's words when he criticizes our praxial philosophy. And in $M M 2$ we never use the word "induction," as Allsup falsely claims. Oddly, Dewey is one of Allsup's favorite philosophers, his main go-to source for all educational issues, but here, Allsup contradicts Dewey's and our validation of the concept of initiation (and/or welcoming), distorts our concept of tradition, and ignores what we say about how praxial music education puts students' personal transformation and full human flourishing at the heart of its concerns. He claims (31) that when we use the word "initiation" we mean teachers should force students to obey the "Law" of a "pre-given framework" (31). We emphatically deny Allsup's unsubstantiated accusation.

Our praxial philosophy embraces and celebrates Dewey's concept of tradition, as well as initiation. When we use these terms, we mean two things. First, we mean that ethical and creative traditions are vital, ever-changing processes, which include the processes that welcome-i.e., receive with delight-guide, facilitate, or mentor newcomers into a musical-interpersonal network of dynamic, dialogical, and social relationships and values. We mean empowering students to enjoy and immerse themselves positively in the doings and makings of the musical praxes that they intend to learn (Elliott and Silverman 2015, 228), not

Elliott, David J., and Marissa Silverman. 2017. On the "truthiness" of Remixing the Classroom. Action, Criticism, and Theory for Music Education 16 (1): 124-67. doi:10.22176/act16.1.124 
what a Master-Father always insists they learn (Allsup, 31), which is what Allsup claims we say.

The natures and values of these relationships, the development of students' musical knowings, doings, and practical wisdom (phronesis), the musical products they create on their own and with others (including teachers), and their growing awareness of the creativities of those who came before them in a tradition-all these variables empower students' creativity and their powers of critical musical reflection, which they apply to the tradition/praxis itself, its strengths and weaknesses, and its many human "goods." The living processes at the heart of a music tradition-and at the heart of praxial music education-act as a launching pad for new ways of thinking and doing and new creations.

We explain and detail all of these issues and concepts, and more, in MM2. Allsup ignores all of them, which is further evidence that his critique of MM2 is one Big Fiction-a whale of a straw man attack on praxial music education.

What we've just documented, and what David's students confirm, undercuts Allsup's claims that our praxial philosophy is the kind of "curatorial pedagogy found in most conservatories" and that it's an archaic "philosophy of artistic apprenticeship" (Allsup, 82).

So, again, Allsup is not correct when he portrays our view of musical traditions and praxes as closed, coded, authoritarian, and norm-governed. Indeed, when we and others refer to a "tradition" in our praxial sense, then the significance of Alasdair MacIntyre's (1984) argument becomes clear. MacIntyre says (cited in $M M 2,50$ ) that when "we" (i.e., children, youth, amateurs, pre-service music educators, music education professors) enter into a musical or educational tradition, we "enter into a relationship not only with its contemporary practitioners, but also with those who have preceded us in the practice, particularly those whose achievements extended the reach of the practice to its present point" (184). In other words, to enter into and "take up" a tradition-of-effort(s) is to step into an ongoing stream of creating (181). From this perspective, it's not only the musical processes and creative achievements of a tradition that music makers and educators learn, but also the musical-educational significance of the tradition itself.

David Hansen supports our praxial perspective: 
tradition does not describe that which remains identical or frozen or that which should be blindly accepted. Tradition once again, is not traditionalism. Everyone in a practice begins as an imitator, but what they imitate and, with effort and luck grow beyond is always on the move, whether subtly or dramatically. In this light, the sense of tradition funds freedom. (quoted in $M M 2,50$ )

In addition to validating our praxial viewpoints, Hansen's words create a problem for Allsup's straw man attack on our praxial concept of tradition. How so? Because Allsup quotes (83) a similar passage from Hansen's work, partly for the purpose of attacking our concept of tradition. That is, in the quotation above, Hansen says: "Tradition once again, is not traditionalism" (italics added), which is what we've been saying. The passage that Allsup quotes includes this phrase: "A feeling for tradition, as contrasted with traditionalism..." (quoted in Allsup, 83).

Allsup chooses to use Hansen's work to support his "open" concept of tradition; at the same time, he chooses Hansen's concept of tradition to misrepresent our concept of tradition as closed, coded, and oppressive. In short, Allsup shoots his criticism of our concept in the foot. His many misleading statements about the so-called "closed" and "coded" nature of our concept of tradition are just truthy claims. If he'd read MM2 carefully, with an open mind, he might have realized that his concept of tradition and ours have a few things in common.

\section{Evaluation and Assessment}

Allsup claims that "the Master-apprentice model values right answers and correct playing at the expense of open encounters," by which he means that "dialogue" isn't important in the praxial philosophy (100). This is a serious misrepresentation of our philosophy, which he attempts to substantiate by using the fallacies of false attribution (he quotes from Elliott 1995, not Elliott and Silverman 2015) and cherry picking.

First of all, as we've said many times, we never talk about "Master"; we talk about ethical teachers-as-mentors-by which we mean ethical guides, coaches, advisors, and collaborators-who always put students' personal growth, individuation, and flourishing first among their concerns. And we never say that music teaching is about valuing "right answers" or "correct playing."

Elliott, David J., and Marissa Silverman. 2017. On the "truthiness" of Remixing the Classroom. Action, Criticism, and Theory for Music Education 16 (1): 124-67. doi:10.22176/act16.1.124 
The point in $M M 1$ (we'll refer to $M M 1$ only because Allsup does) and our elaborated position in $M M 2$ is that assessments of student's musicing and musical understanding should be based "primarily"-never exclusively-on formative assessments of their music making over time, as they develop at their own pace. Assessments should not be based exclusively on verbal or written tests of students' knowledge about their music-making processes or their verbal knowledge of music history, or theory. Nowhere do we say that dialogues are unimportant. Of course students and teachers should discuss together many facets of musicing.

MM2 states that music (like dancing and drama) is a performing art that involves embodied knowings and processes that differ from those involved in (say) creative writing, painting, and so forth. Performing, improvising, arranging, and so forth necessarily involve discussions of all sorts of things-this is both essential and central in our praxial philosophy-but to make music, dialogues about music must give way to the actual doing of music in action.

$M M 1$ (and now "we" in $M M 2$ ) says that praxial music education holds that verbal knowledge "ought to be filtered into the teaching-learning situation parenthetically and contextually" (Elliott 1995, 61). Verbal concepts about music "ought to emerge from and be discussed in relation to ongoing efforts" to make music musically. Notice: "be discussed"-between teachers and students, which, in praxial music education, means ethical dialogues.

In contrast to the above, Allsup says:

It is no controversy to say that the Master listens primarily to assess an apprentice's understanding of a specific style or convention. "In terms of evaluation," writes Elliott, "the primary point to make now is that a student's level of musical understanding demonstrates itself primarily in the quality of his or her music making, not in what a student can tell us about musical works... Verbal information (or formal knowledge) about music is no substitute for the ultraspecific nonverbal conception of musical works that a student exhibits when he or she performs (improvises, composes, arranges, or conducts) intelligently" [Elliott 1995, 75]. (100)

Allsup isolates the above without consideration of what precedes this in MM1: that in the moment-to-moment swirl of activities in music classrooms, teachers diagnose-by which $M M 1$ means "observe" and assess formatively"what our students are giving attention to, what they fail to notice and understand, what they find difficult to solve, what they feel right or wrong about musically, and so on" (75). In such situations, teachers guide students' musical 
thinking-in-action while they're performing, improvising, composing (etc.) by using "different languages of instruction [notice: languages of instruction] including modeling, demonstrating, explaining in words, gestures, diagrams, and metaphors" (75). In praxial music education, conversations between students and teachers are inevitable and, in our view, they should be respectful and constructive.

In the praxial philosophy, the aim is not to evaluate students' verbal knowledge about their processes of musicing by giving them written tests. Doing so is not "knowledge fair" because musical understanding-not simply "musicianship" (Allsup, xii) - consists of musicianship + listenership, which altogether involves 16 forms of musical thinking and knowing, most of which are embodied (Elliott and Silverman 2015, 195-231). Related to the intricate and integrated dimensions of robust musical understanding, please read in $M M 2$ our detailed discussion of the nature, values, and creative strategies that teachers can use to empower students' musical interpreting (243-50). Praxial strategies include dialogues, explorations, experimentations, supportive risk taking, and "multiple drafts" of students' interpretations. Creative and expressive interpreting, like all forms of musical creativity, includes continuous cycles of generating, reflecting, and selecting musical ideas.

Let's develop these points with another example that is provided in both $M M 1$ and $M M 2$ : skiing.

If we tell you that coauthor Marissa knows how to ski, and if she explains the why-what-and-how of downhill skiing, will this convince you that she really knows how to ski? Perhaps not. You will want tangible proof of her skiing knowhow. You will want to see her ski successfully on several occasions before you grant that, "Yes, Marissa, you really do know how to ski." Her words about skiing are not enough. The proof of her "skiership" lies in the effectiveness of her skiing actions.

And the same holds for you as her evaluator. That is, to understand and assess Marissa's abilities as a downhill skier, you must also possess some actual, felt experience, or degree of skiing competency-this does not mean an exceedingly high level of expertise-in downhill skiing yourself... Knowing how to do something and knowing how to watch or listen to someone do something are two sides of the same coin. (MM2, 213)

So this is partly what we mean when we argue that

understanding the quality of a person's musical understanding should focus mainly on what a musicer exhibits in her unified, real-time musicing-listening.

Elliott, David J., and Marissa Silverman. 2017. On the "truthiness" of Remixing the Classroom. Action, Criticism, and Theory for Music Education 16 (1): 124-67. doi:10.22176/act16.1.124 
This is why nonmusical [i.e., disinterested] school administrators and politicians are in no position to understand [or assess] what music teachers or CM facilitators are doing, or what school music students are attempting to learn (MM2, 214).

Allsup omits to report to readers, let alone reflect on, any details of the concepts and issues we've just outlined-all of which undercut his simplistic and erroneous argument (e.g., xii) that $M M 2$ pivots on musicianship in the old, "institutional" sense of manual skills, and omits dialogues.

Musically, an ongoing aim of praxial music education is to guide students toward expressive and creative performing, improvising, and composing (etc.) which take advantage of varied approaches to creative and emotionally expressive teaching for the achievement of many musical "goods": joy, social fellowship, selfefficacy, ethical personal and musical identities, creativity, health and wellbeing-in a word: eudaimonia.

So Allsup's claim that praxialism is about "the Master [who] listens primarily to assess an apprentice's understanding of a specific style or convention," and teachers who focus on "correct playing" and "right answers," is wildly false.

\section{Allsup's Sleight of Hand}

At this point, we need to highlight one of Allsup's "special" criticisms of our philosophy, which relates to other accusations he makes and other fallacies in his critique.

In proper, responsible scholarship, critics do not misquote an author's words or delete words and/or sentences in ways that deliberately misrepresent an author's work. This amounts to withholding evidence that negates the critic's claims. But this is what Allsup does with a paragraph in $M M 2$, which we quote in full below. We've italicized the words and passages that Allsup deletes. Once you read our original paragraph, please compare it to Allsup's version.

Musical communities shape preferences and decisions (formally and informally) about what counts as "musical" in a specific context of musicing and listening. Thus musical communities function in two ways. They ask musicers and listeners to respect and work within present boundaries. At the same time, they invite musicers and listeners to go beyond current understandings and values to create highly original musical products, and perhaps whole new musical praxes. So, musical communities and their priorities and values are never static, but constantly in flux. (Elliott and Silverman, 229).

Elliott, David J., and Marissa Silverman. 2017. On the "truthiness" of Remixing the Classroom. Action, Criticism, and Theory for Music Education 16 (1): 124-67. doi:10.22176/act16.1.124 
Allsup selectively quotes from the above, thus changing our meanings entirely. Instead of the full quotation (above), Allsup writes this:

Mentors [Allsup's word, which does not match the broader and deeper meaning of our words: "musical communities"] in turn, "shape preferences and decisions (formally and informally) about what counts as 'musical' in a specific context of musicing and listening... They ask musicers and listeners to respect and work within present boundaries." (MM2 cited in Allsup, 82)

Allsup's "re-write" of our paragraph enables him to reinforce several false arguments he makes in Remixing such as: our praxial philosophy is opposed to creativity; our praxial concept of musical communities (he says "mentors" and uses the word in a negative sense: "Masters") only asks "musicers and listeners to respect and work within present boundaries"; our praxial concept of musical communities (which includes schools and traditions) is static; and our philosophy does not encourage musicers, listeners, or communities (which include teachers) to go "beyond current understandings and values to create highly original musical products, and perhaps whole new musical praxes."

Clearly, we say the reverse in our original paragraph in $M M 2$.

\section{Classrooms and Apprentices}

\section{Classrooms}

Now a few words about classrooms and Allsup's erroneous claims about our socalled use of "apprentice."

The moment-to-moment, fluid, and local nature of classrooms is partly what makes teaching an extremely challenging endeavor. Music teachers must reflect on and carry out their musical and educational responsibilities in relation to practical reasoning and "standards of care," not standardized curricula, objectives, or methods. As Hannah Arendt (1958) emphasizes, because praxis is inherently social-because praxis always occurs within a complex web of human relationships and individuals' needs and desires (e.g., all educational and musical interactions)-the outcomes of praxis can never be predicted with certainty. Thus, musical and educational praxes present risks because they require music makers and teachers to make informed and "care-full" judgments about and "diagnoses" (i.e., informed observations) of students' needs and goals, and to determine how 
to plan, act, and achieve musical and educational outcomes in/for specific learning situations (Carr and Kemmis 1986, 190).

It goes without saying that if teachers are only teaching musical techniques or information about music, then they are not engaged in praxis and praxial music education.

Again, we emphasize the responsibility of music teachers to enable, empower, and "welcome" students to develop their musical abilities and interests to listen, perform, improvise, compose, arrange, conduct, lead, and otherwise make music. And we agree that there's nothing wrong with teaching musical skills and techniques, as long as it's recognized that skill-teaching is only one part of the many processes needed to enable students to make, listen to, understand, and learn how to apply their musical abilities ethically, imaginatively, and creatively.

What we're adding and emphasizing here, however, is that if teachers are committed to teaching music professionally-by which we mean teaching effectively, educatively, and with an ethic of care-and if teachers want to be engaged in praxial music education, then teachers should teach music making and listening with a conscious commitment to "care-guided" and ethically-guided actions that go far beyond a simplistic concern for technically accurate "sound making."

When music education is ethically guided-when we teach people not only in and about music, but also through music (as we explain in Chapter 1, MM2), we empower students to achieve eudaimonia, which is the ultimate aim of praxis and a central aim of our praxial philosophy of music education, not coded and norm-governed forms of musicing, listening, or musical traditions.

And so instead of using the notion of "Master-apprentice" in $M M 2$, we use the concept of mentor. It's doubtless true that the vast majority of music teachers and scholars understand that a "mentor" is not a heavy-handed and harsh Master, but an ethical and supportive guide and advisor. Among other characteristics, mentors usually fade in-and-out of classroom leadership roles, as we recommend (e.g., 433-44), and engage students in their own assessments.

\section{Apprentice}

In addition to the fact that we never use Master, ${ }^{1}$ or Master-apprentice, we only use "apprentice" in relation to three discussions by a few scholars (i.e., Collins, Brown, and Newman 1989; Gardner 1991; Higgins 2012) who suggest that a 
"cognitive apprenticeship" (424), or a practicum-apprentice model, offers one approach to addressing some aspects of teaching and learning, which include situations where both the "mentor" and the "apprentice" are students. As Howard Gardner (1991) says, the practicum-apprenticeship model

may well be the means of instruction that builds most effectively on the ways in which most young people learn ... Such forms of instruction are heavily punctuated with sensorimotor experiences and with the contextualized use of firstorder forms of symbolization, such as natural language and simple drawings and gestures. To the extent that they feature more formal notations or concepts, these are introduced to the learner directly in the context in which they are wanted, and the learner sees for himself the ways in which they may be applied. (124)

Chris Higgins (2012) concurs with Gardner, but states his support in relation to practices:

Through participating in a practice, we learn how to appreciate and realize the "internal goods" of the practice, internal because their value can only be articulated in the terms of the practice, can only be appreciated by those who have apprenticed themselves to it, and cannot be cashed out in instrumental terms. (224).

\section{Musical Understanding and Musical Meanings}

In regard to our praxial concepts of musical understanding and musical meanings, Allsup says: “...in Music Matters, Elliott writes that anyone 'who does not possess the musicianship to participate in a musical community is not a competent judge of its internal goods' [MM1, 179]. Insulated from critique, the Master is also Critic, a synthesis that effectively arrests debate and disallows difference" (100).

Allsup argues that: "'Musicianship is practice specific,' he [Elliott] emphasizes. It is coded and norm-governed, and dependent on context" (23-here Allsup quotes $M M 1,54$; he then cites and selectively quotes, in an endnote, $M M 2,208$, Allsup, 146); "musicianship is relegated to Law-like generalizations, which are manufactured within "a tradition that trades in the faux-authentic and the protoauthoritative" (Allsup, 24) habits of a social practice.

Elliott, David J., and Marissa Silverman. 2017. On the "truthiness" of Remixing the Classroom. Action, Criticism, and Theory for Music Education 16 (1): 124-67. doi:10.22176/act16.1.124 


\section{Musical Understanding}

Allsup is wrong because he fails to refer to, let alone discuss, our full concept of musical understanding-i.e., musical understanding $=$ musicianship + listenership-that's expanded significantly in $M M 2$ (Elliott and Silverman 2015, 195235). He only refers to "musicianship" in $M M 1$ (the fallacy of false attribution again), and he equates our concept of "musicianship" with what (he thinks) "institutional," CEO-type directors mean by the term, which is, apparently, skills and concepts.

Because Allsup omits everything we say about the nature of musical understanding (all of which negates his false assertions), we'll revisit and expand the brief sketch of musical understanding that we provided in the Evaluation and Assessment section of this discussion.

We conceive musical understanding in terms of two interdependent and mutually interactive dimensions of musical thinking and knowing (MTK, for short): musicianship and listenership. As you see in our diagram of musical understanding, below, Musicianship involves eight open types of MTK, and Listenership involves eight open types of MTK: Procedural, Verbal, Experiential, Situated, Intuitive, Appreciative, Ethical, and Supervisory, all of which are rooted in our holistic, 4E-concept of personhood, which unites and integrates: body, brain, mind, consciousness, and non-consciousness, which, in turn, enable a wide range of integrated human capacities: attention, cognition, emotion, memory, volition (etc.), all of which enable musicing, listening, creativity, educating, learning, and so forth.

We need to emphasize that our concepts of musical understanding, MTKs, and the $4 \mathrm{E}$-concept of personhood are supported by a wide range of contemporary scholars in neuroscience, the philosophy of mind, holistic cognitive psychology (etc.). Very briefly, the $4 \mathrm{E}$-concept argues that persons are simultaneously embodied, embedded, enactive, and extended beings. Thus, students can/do develop gradually the 16 MTKs of musical understanding in educative school music programs largely because 14 of them are fundamentally embodied and enactive-not narrowly cognitive-forms of thinking and knowing. 
Here is our diagram of musical understanding that we present in $M M 2$.

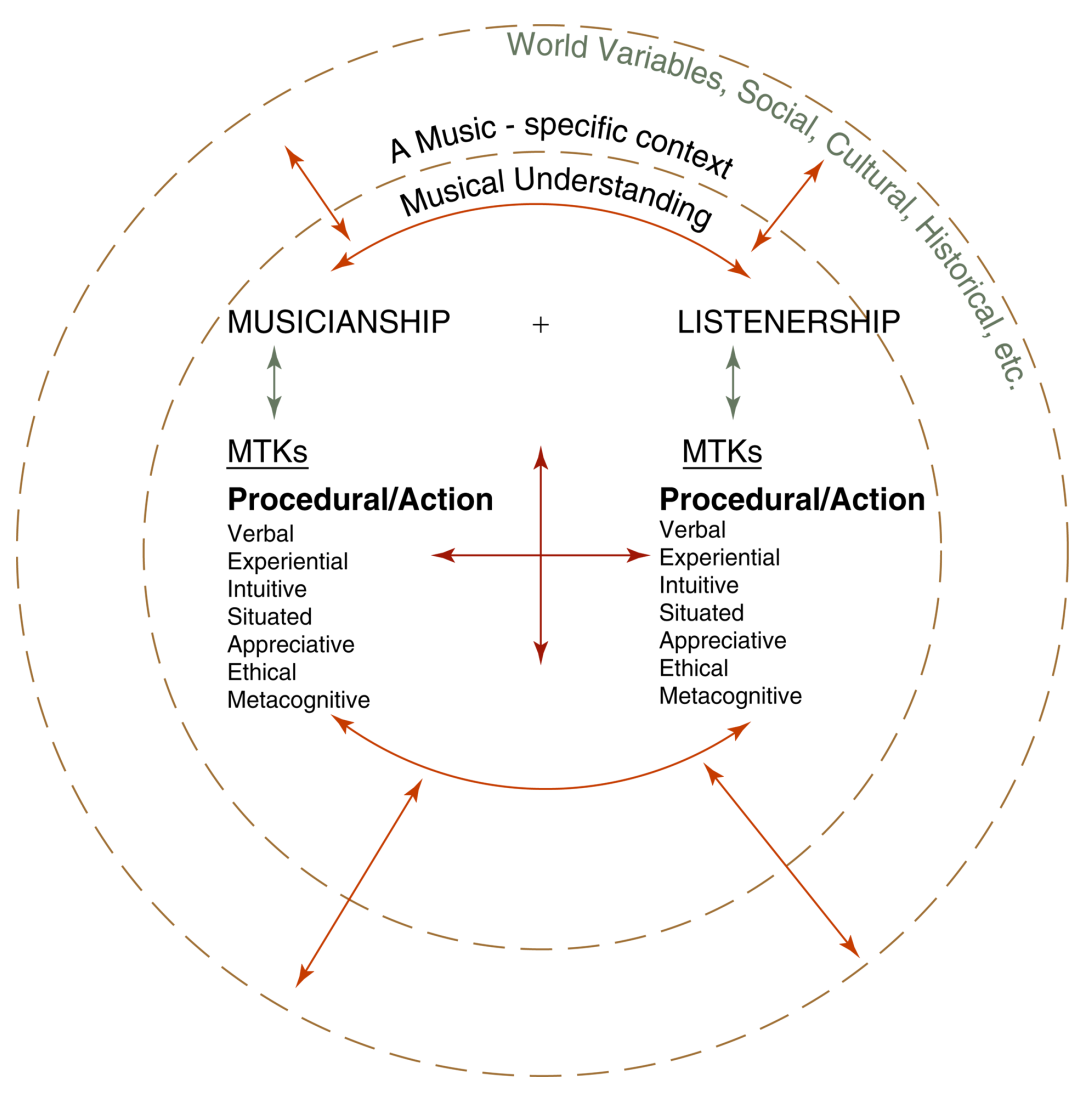

The vertical arrows emphasize that all categories of MTK that make up musicianship and listenership are related to all the others, and all types of musical thinking and knowing interact dynamically when someone is making musicperforming, improvising, composing, arranging, conducting, and so forth-and listening to music while musicing or listening for its own sake.

The horizontal arrows emphasize that when someone is musicing, all types of MTK in musicianship interrelate and interweave with all types of MTK in listenership.

As a child, teenager, or adult progresses along a continuum of ability levelse.g., novice, to beginner, to more proficiency as a music maker/listener-each category of MTK becomes deeper, richer, and more integrated with all other categories of MTK.

Elliott, David J., and Marissa Silverman. 2017. On the "truthiness" of Remixing the Classroom. Action, Criticism, and Theory for Music Education 16 (1): 124-67. doi:10.22176/act16.1.124 
Indeed, we posit that as each category of MTK develops and matures, people will become more empowered as reflective and creative music makers. For example, imagine a child who wants to learn to sing or play a specific instrument in order to perform the pieces of a specific kind of Music. If she's fortunate to have an educative music teacher as her mentor-i.e., coach, guide, advisor, or collaborator, not Master-she'll be gradually immersed-to the extent she chooses to be-in the kind of musical understanding and the MTKs that propel the music praxis she's engaged in. Over time-with practice, increasing experiences, and musical guidance-she'll likely grow from a novice, to a beginner, to an advanced beginner, and then develop more nuanced musical competencies and proficiencies, as she wishes.

Note carefully, please, that our praxial philosophy is focused on developing amateurs and amateuring, not professionals.

When someone is listening to music without musicing, all forms of thinking and knowing that we list under listenership interact with each other dynamically.

Please know that the circle of dashes surrounding musical understanding emphasize that the MTKs that constitute musicianship and listenership will differ (to greater and lesser degrees) from musical praxis to musical praxis. For example, if a jazz drummer understands how to perform and improvise musically in a jazz combo, or a big band jazz ensemble, this doesn't automatically mean he/she understands how to perform or improvise musically in a Dagomba drumming ensemble.

The same theme applies in sports: just because someone is a good amateur basketball player, this doesn't mean that he/she can automatically become, or wants to become, a good baseball player. It's possible of course, but each sport is embedded in an intricate, intersubjective network of thinking, knowing, doing, ethical interactions, and so on.

The artistic, social, cultural, ethical, emotional, and other aspects of two different musical-style communities will involve differences across a wide spectrum, from very similar to dramatically different. Thus, even though the sixteen categories of MTK that make up musicianship and listenership in jazz drumming and Dagomba drumming will have some basic knowings in common, the precise nature of these MTKs will be different because each kind of drumming is historically, socially, and culturally bounded-softly or rigidly. The participants in each 
praxis will develop and "deploy" musical creations, values, expectations, and other aspects of themselves and their cultures in many ways.

Musical understandings are fueled and driven by the musical processes (performing, improvising, listening, etc.) that lead to the creation of the musical products (compositions, improvisations, and so forth) of a specific Music (e.g., Gamelan Jegog music, Rap Metal, Ska Punk, Opera Buffa). Each musical praxis thrives and changes according to how the music makers and listeners of that praxis consciously or nonconsciously develop, apply, teach, update, or hybridize the various categories of MTK that fuse together in the actions of music makers and listeners. From this perspective, musical understanding is implicit and explicit in each of the four basic dimensions of a musical praxis that we explained in the music section of this paper and in MM2 (Chapters 2 and 3).

Just a few more points. As we state in $M M 2$, musical understanding-like all concepts in $M M 2-$ is porous, flexible, and open. Like all forms of genuine understanding, musical understanding is not an end point but a continuous process. It grows such that a complex web weaves inward and outward. It develops as the sixteen kinds of MTK mature and interweave with each other.

Additionally, we propose that although it's appropriate to use the word "understanding" in the social constructivist sense of enabling people to develop, coconstruct, and apply particular kinds of knowing-doing, the word is also tied to empathy, as in "being an understanding person or teacher." So possessing musical understanding as educators means, partially, being sensitive to the feelings, thoughts, difficulties, needs, and desires of the people in our care (MM2, 202). Educative and compassionate teaching requires us to be aware of and alert to how students feel about how they're learning to make and listen to music, how they feel about and respond to what we're doing as educators, how others in their learning community respond to them, or not, and how we can improve students' experiences in these regards. Viewing understanding through this intersubjective lens is essential to teach, guide, and facilitate music musically, effectively, and meaningfully.

Such understanding is not a matter of "induction," regardless of Allsup's claim that MM2 uses this term. Instead, developing musicianship and listenership includes welcoming students into and motivating them to immerse themselves in the doings and makings of the musical praxes they intend to learn. So

Elliott, David J., and Marissa Silverman. 2017. On the "truthiness" of Remixing the Classroom. Action, Criticism, and Theory for Music Education 16 (1): 124-67. doi:10.22176/act16.1.124 
the nature of the musical understanding underlying any praxis of music making and listening has its roots in specific communities of practitioners who share and advance specific forms of musical thinking and doing. Musical praxes swirl around the efforts of practitioners who originate, maintain, change, adapt, and/or refine specific ways and means of musicing, as well as musical histories, legends, and lore. As we explained in our introduction, above, because musical praxes and traditions are human processes, their natures run the gamut from less to more porous, protean, fluid, and open phenomena. Such fluidity is at the heart of living traditions. As Bowman states:

Living traditions are temporally extended arguments about what the internal goods of a practice are. Paradoxically, then, one can't express a new vision without doing so through the lenses provided by tradition. To extend a tradition one must amend it. Failing to do so doesn't create a new tradition, it steps outside it altogether. (cited in $M M 2,50$ ).

When Allsup mentions (xii) or quotes short passages about "musicianship" (e.g., 16) from $M M 1$ and $M M 2$, he omits all details of what we say about the relationships between musicianship and listenership and students and musical traditions. And he doesn't mention (let alone discuss) the many types of embodied and networked MTKs that we explain. Thus, whatever he says about "musicianship" is just another example of his use of slanting: intentionally omitting pertinent material from $M M 2$ to hide evidence that's important to our arguments and that undercuts his false claims.

\section{Musical Meanings}

Allsup states: "David Elliott's philosophy of 'praxial' music education ... asks practitioners to locate meanings in the identification of a context-dependent grammar... Once musical properties can be identified and understood, music can be taught in ways that are consistent with established conventions" (22-3).

Allsup is wrong. When we discuss musical meanings, we don't ask students or teachers to "locate meanings in the identification of a context-dependent grammar," or to identify "musical properties." We posit and discuss our multidimensional concept of human-musical meanings in our chapter on Musical Products (282-304) in MM2.

Elliott, David J., and Marissa Silverman. 2017. On the "truthiness" of Remixing the Classroom. Action, Criticism, and Theory for Music Education 16 (1): 124-67. doi:10.22176/act16.1.124 
We propose that musical "products"-e.g., compositions and improvisations of vocal and instrumental music of all kinds, as well as participatory music making, digital-audio musicing, film music, etc.-can have at least nine layers of related musical meanings that people can experience in numerous ways. Our embodied capacities of attention, perception, cognition, emotion, memory, and volition enable us to make sense of, construct, feel, body-map, understand, and remember a very wide range of musical, personal, social, intersubjective, and other meanings that can arouse and express emotions.

Put another way, music is a protean art. Music makers, listeners and, therefore, musical products of all kinds have an enormous capacity to soak up, interact with, enfold, mold, modify, reconfigure, represent, communicate, and heighten the effects of an unlimited range of non-sonic media, technologies, other musics, and multiple art forms. Accordingly, music makers (amateur or professional, young or old, and so forth) and their musical creations have the even broader and deeper potential to interpret and predict social and cultural values and issues, including economic and political trends.

Think of the many ways music and musical products combine with, enhance, alter, and heighten the meanings and emotional effects of the words, bodily actions, visual, and acoustic dimensions of rituals, chants, madrigals, cantatas, hymns, dramas, songs of all kinds in all cultures, and the librettos of operas and musical theater productions, not to mention protest songs, war songs, war dances, and peace songs. And consider how musical products combine easily with many kinds of movement and visual media: dances, films, television shows, videos, video games, news broadcasts, light shows, rallies, celebrations, and sports of all kinds.

In the diagram below, we provide an overview of our multidimensional concept of musical products. Briefly stated, this diagram represents what pieces of music are "good to listen for," and what human and musical "goods" they can yield for music makers and listeners who engage with them. From another perspective, this provisional, open "map" of musical products suggests that performers should consider the potential layers of meaning in a piece they're preparing to interpret and perform (e.g., a pop song, a concerto, a piece composed for a marching band to perform at a half-time show), or what composers either know intuitively or conceptually about the layers of meaning that can be created and

Elliott, David J., and Marissa Silverman. 2017. On the "truthiness" of Remixing the Classroom. Action, Criticism, and Theory for Music Education 16 (1): 124-67. doi:10.22176/act16.1.124 
expressed in a piece of music. Our concept of musical products can also be used as an open and flexible guide for teachers who are teaching music listening and all other forms of musicing.

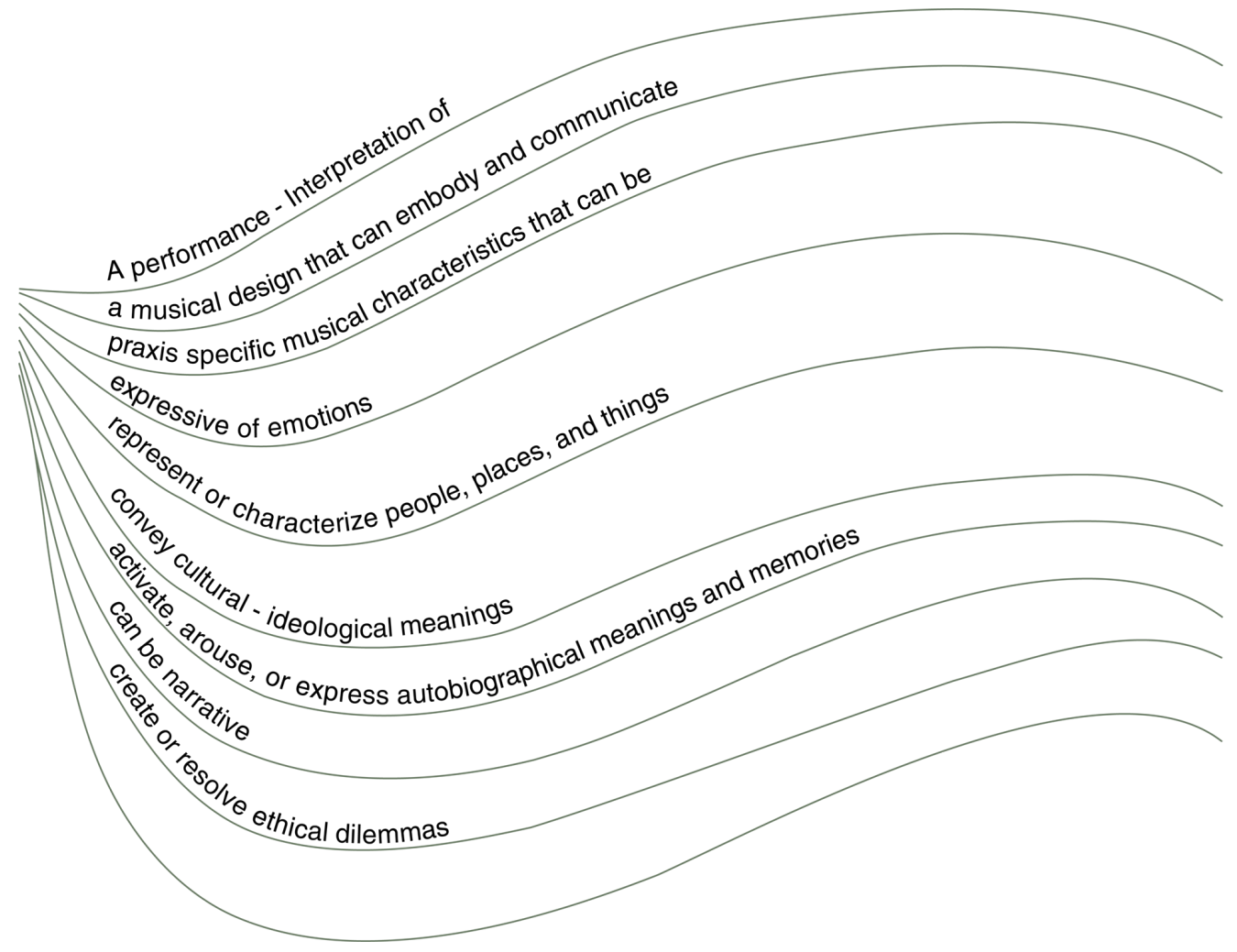

Our praxial premise is that musical products are much, much more than sound structures or elements, or what Allsup calls "properties." Pieces of music aren't simply chains of different sonic "properties." Composers and arrangers create pieces to communicate artistic-social meanings, to create opportunities for musicers and listeners to interpret the meanings they can or choose to hear in compositions, and to arouse listeners' emotions by expressing various meanings and emotions.

To explain the diagram in a little more detail, we conceive a musical product (e.g., a composition of some kind, an improvisation, etc.) as: (1) a performanceinterpretation of (2) a musical form-content design of some kind that has been created by any kind of music maker (composer, arranger, improviser, record

Elliott, David J., and Marissa Silverman. 2017. On the "truthiness" of Remixing the Classroom. Action, Criticism, and Theory for Music Education 16 (1): 124-67. doi:10.22176/act16.1.124 
producer, etc.). And because dimensions (1) and (2) are created by music makers in a specific musical praxis who share a certain type or types of musical understanding in common, the audible features of the musical products they make can embody and communicate (3) musical style characteristics. For example, people who've heard cool jazz (e.g., the compositions, performances, and improvisations of Miles Davis), and who have some degree of tacit or verbal cool-jazz understanding will know that "Freddie Freeloader" is an example of cool jazz because it embodies and conveys the many stylistic-musical characteristics of cool jazz.

Broadening our concept, we argue that musical products often involve some combination of six other interrelated dimensions of musical meaning. Pieces and performances have the potential to: (4) be expressive of emotions; (5) represent or characterize people, places, and things; (6) convey cultural-ideological meanings; (7) arouse and express autobiographical meanings and memories, or cause listeners to create new musical memories; (8) musically "narrate," as when a piece of music expresses an event in a person's life; and/or (9) create or resolve ethical dilemmas.

Of course, because every musical praxis is socially situated, and because every music maker and listener is an individual who listens to his/her musics from his/her own personal, social, cultural, gendered, and other perspectives, there's no end to the ways people can and do interpret musical products and "make meanings" while musicing and listening. So the layers of musical meaning seen in our diagram, above, must be taken as provisional. There's no doubt that any number of musical praxes and musical products can embody and give listeners more opportunities to imagine and experience other kinds of musical meanings. In short, "this concept is 'open' for/to [further] interpretation and imaginative application" (which is exactly what we say in $M M 2,285$ ) by music makers, listeners, and teachers. Moreover, we emphasize that our concept of musical products and meanings is just a working concept of what teachers, music makers, and listeners may wish to listen for, teach, and bring into being when they perform, compose, improvise, conduct, record, and so forth.

Thus, there's no way that musical meanings are/can be found in some kind of "grammar" or simplistic "musical properties," as Allsup claims we say. Indeed, this is not what we say, as you see from the above and from what you can read in vastly more detail in $M M 2$ (282-304).

Elliott, David J., and Marissa Silverman. 2017. On the "truthiness" of Remixing the Classroom. Action, Criticism, and Theory for Music Education 16 (1): 124-67. doi:10.22176/act16.1.124 


\section{Conclusion}

The Introductions to both $M M 1$ and $M M 2$ ask readers to please read both books carefully. Otherwise, it's likely that some readers will misunderstand or mistake what we're actually saying.

The concepts and arguments presented in Music Matters unfold gradually in and across all fourteen chapters. There are many lines and layers of ideas that we develop, elaborate, refine, and integrate sequentially. Therefore, the complete meaning of "praxial music education" comes into full view only when you (1) zoom in on specific details, (2) zoom out to place specific details in the larger contexts of our arguments, and (3) repeat this process back and forth and continuously while reading and applying these ideas to your own conduct [the ways you engage with the book] and circumstances. $(M M 2,21)$

In short, developing an understanding of our praxial philosophy requires a careful reading of the entire book (Elliott and Silverman 2015, 21), isolating "no details prematurely as more or less important than the others" (Elliott 1995, 15).

In our view, Allsup's reading of our praxial philosophy should have been much more conscientious. Which brings us to MacIntyre's (2011) reflections on truth versus truthiness, or "falsity":

Truth and falsity are not just a matter of the relationship between asserted sentences and that about which they are uttered, but also a matter of the relationship between minds and the realities about which they think ... Truthfulness is indispensable to those who recognize that without it their relationships with others cannot be relationships of justified trust and that without such relationships they will often be frustrated in, among other things, achieving understanding. (336)

\section{About the Authors}

David J. Elliott is Professor of Music and Music Education at New York University. He joined NYU after 28 years as Professor of Music Education at the University of Toronto. As a visiting professor, he has served at Indiana University, Northwestern University, the Irish World Academy of Music, and the University of Guangzhou, among others. With Marissa Silverman, he is co-author of Music Matters: A Philosophy of Music Education, $2^{\text {nd }}$ edition (2015), co-editor of Artistic Citizenship: Artistry, Social Responsibility, and Ethical Praxis (2016), and co-editor of Community Music Today (2012). He has published 45 peerreviewed journal articles, 36 chapters in edited books, and he has presented more than 300 invited keynote papers/university lectures in 46 countries. Among other volumes, his chapters appear in The Oxford Handbook of Musical Identi-

Elliott, David J., and Marissa Silverman. 2017. On the "truthiness" of Remixing the Classroom. Action, Criticism, and Theory for Music Education 16 (1): 124-67. doi:10.22176/act16.1.124 
ties, The Oxford Handbook of Philosophy in Music Education, The Child as Musician, The Oxford Handbook of Music Education, and Music, Health, and Wellbeing.

Marissa Silverman is Associate Professor of Music and Music Education at the John J. Cali School of Music, Montclair State University, NJ. A Fulbright Scholar, she has published invited chapters in recent Oxford University Research Handbooks, as well as journal articles in the International Journal of Music Education, the British Journal of Music Education, Action, Criticism, and Theory for Music Education, Research Studies in Music Education, Music Education Research, the International Journal of Community Music, and Visions of Research in Music Education. She is also co-author (with David Elliott) of the 2nd edition of Music Matters: A Philosophy of Music Education; co-editor of Community Music Today; and co-editor of Artistic Citizenship: Artistry, Social Responsibility, and Ethical Praxis. As a secondary school teacher, she taught general music, band, and English Literature at Long Island City High School (Queens, New York).

\section{References}

Allsup, Randall. 2016. Remixing the classroom: Toward an open philosophy of music education. Bloomington, IN: Indiana University Press.

Allsup, Randall. 2010. Philosophical perspectives on music education. In Critical issues in music education: Contemporary theory and practice, edited by Harold F. Abeles and Lori Custodero, 39-60. New York, NY: Oxford University Press.

Arendt, Hannah. 1958. The human condition. Chicago, IL: University of Chicago Press.

Barrett, Margaret. 2007. Music appreciation: Exploring similarity and difference. In International handbook of research in arts education, edited by Liora Bresler, 605-20. The Netherlands: Springer.

Bowman, Wayne. 2012. Practices, virtue ethics, and music education. Action, Criticism, and Theory for Music Education 11(2): 1-19. http://act. maydaygroup.org/articles/Bowman11_2.pdf

Bowman, Wayne. 2014. The ethical significance of music-making. Music mark magazine, 3. https://jfin107.wordpress.com/scholarly-paper-the-ethicalsignificance-of-music-making-by-wayne-bowman/

Elliott, David J., and Marissa Silverman. 2017. On the "truthiness" of Remixing the Classroom. Action, Criticism, and Theory for Music Education 16 (1): 124-67. doi:10.22176/act16.1.124 
Bowman, Wayne, and Lucia Ana Frega, eds. 2012. The Oxford handbook of philosophy in music education. New York, NY: Oxford University Press.

Burbules, Nicholas, and Rupert Berk. 1999. Critical thinking and critical pedagogy: Relations, differences and limits. In Critical theories in education: Changing terrains of knowledge and politics, edited by Thomas Popkewitz and Lynn Fendler, 45-65. New York, NY: Routledge.

Burnard, Pamela. 2005. What matters in general music? In Praxial music education, edited by David J. Elliott, 267-80. New York, NY: Oxford University Press.

Campbell, Patricia. 2008. Musician and teacher: An orientation to music education. New York, NY: W.W. Norton \& Company.

Carr, Wilfred, and Stephen Kemmis. 1986. Becoming critical: Education, knowledge, and action research. Philadelphia, PA: Falmer Press.

Collins, Alan, John Seely Brown, and Susan Newman. 1989. Cognitive apprenticeship: Teaching the crafts of reading, writing, and mathematics. In Knowing, learning and instruction: Essays in honor of Robert Glaser, edited by L. Resnick, 453-4. Hillsdale, NJ: Erlbaum.

Dewey, John. 1934. Art as experience. New York, NY: G.P. Putnam’s Sons.

Dewey, John. 1938/1963. Experience and education. New York, NY: Collier Books.

Dewey, John. 1974. John Dewey on education: Selected writings. Chicago, IL: University of Chicago Press.

Elliott, David J. 1995. Music matters: A new philosophy of music education. New York, NY: Oxford University Press.

Elliott, David J. 2007. "Socializing" music education. Action, Criticism and Theory for Music Education, 6(4): 60-95. http://act.maydaygroup.org/ articles/Elliott6_4.pdf

Elliott, David J. 2012. Music education as/for artistic citizenship. Music Educators Journal 99(1): 21-7.

Elliott, David J. 2014. Artistic citizenship, personhood, and music education. In Giving voice to democracy in music education, edited by Lisa DeLorenzo, 13-35. New York, NY: Routledge.

Elliott, David J., and Marissa Silverman. 2017. On the "truthiness" of Remixing the Classroom. Action, Criticism, and Theory for Music Education 16 (1): 124-67. doi:10.22176/act16.1.124 
Elliott, David J., and Marissa Silverman. 2015. Music matters: A philosophy of music education, second edition. New York, NY: Oxford University Press.

Elliott, David J., and Marissa Silverman. 2015b. A response to commentaries on Music matters: A philosophy of music education, second edition (2015). Action, Criticism, and Theory for Music Education 14(3): 106-130. http://act.maydaygroup.org/articles/ElliottSilverman14_3.pdf

Elliott, David J., Marissa Silverman, and Wayne Bowman, eds. 2016. Artistic citizenship: Artistry, social responsibility, and ethical praxis. New York, NY: Oxford University Press.

Freire, Paulo. 1970. Pedagogy of the oppressed. New York, NY: Bloomsbury.

Gardner, Howard. 1991. The unschooled mind. New York, NY: Basic Books.

Goble, J. Scott. 2003. Perspectives on practice: A pragmatic comparison of the praxial philosophies of David Elliott and Thomas Regelski. Philosophy of Music Education Review 11(1): 23-44.

Higgins, Christopher. 2012. The good life of teaching: An ethics of professional practice. Hoboken, NJ: Wiley-Blackwell.

Jorgensen, Estelle. 2006. On philosophical method. In MENC handbook of research methodologies, edited by Richard Colwell, 91-101. New York, NY: Oxford University Press.

MacIntyre, Alasdair. 1984. After virtue, second edition. Notre Dame, IN: University of Notre Dame Press.

MacIntyre, Alasdair. 2011. Hard truths, soft lies, solitary thoughts. Analysis Reviews 71 (2): 333-41.

McCarthy, Marie. 2000. Music matters: A philosophical foundation for a sociology of music education. Bulletin of the Council for Research in Music Education 144: 3-9.

Noddings, Nel. 1992. Caring: A feminine approach to ethics and moral education. Berkeley, CA: University of California Press.

Noddings, Nel. 2010. Moral education and caring. Theory and Research in Education. 8(2): 145-151.

Elliott, David J., and Marissa Silverman. 2017. On the "truthiness" of Remixing the Classroom. Action, Criticism, and Theory for Music Education 16 (1): 124-67. doi:10.22176/act16.1.124 
Regelski, Thomas A. 2005. Critical theory as a foundation for critical thinking in music education. Visions of Research in Music Education 6. http:// www.rider.edu/ vrme

Reichling, Mary. 1996. On philosophical method. Philosophy of Music Education Review 4(2): 117-27.

Reimer, Bennett. 1970. A philosophy of music education. Prentice-Hall.

Reimer, Bennett. 1989. A philosophy of music education: Advancing the vision. Third edition. Upper Saddle River, NJ: Prentice-Hall.

Reimer, Bennett. 1996. Music matters book review. Bulletin of the Council for Research in Music Education 128: 59-89.

Reimer, Bennett. 2003. A philosophy of music education: Advancing the vision, third edition. Upper Saddle River, NJ: Prentice Hall.

Schafer, R. Murray. 1965. The composer in the classroom. BMI Canada Limited: Don Mills, Ontario.

Silverman, Marissa, Susan A. Davis, and David J. Elliott. 2014. Praxial music education: A critical analysis of critical commentaries. International Journal of Music Education 32 (1): 53-69.

Turino, Thomas. 2008. Music and social life: The politics of participation. Chicago, IL: University of Chicago Press.

Turino, Thomas. 2016. Music, social change, and alternative forms of citizenship. In Artistic citizenship: Artistry, social responsibility, and ethical praxis, edited by David J. Elliott, Marissa Silverman, and Wayne Bowman, 297-312. New York, NY: Oxford University Press.

Wisnewski, J. 2010. Killing the Griffins: A murderous exposition of postmodernism. In Introducing philosophy through pop culture, edited by William Irwin and David Johnson, 238-46. West Sussex, U.K.: John Wiley \& Sons.

\section{Notes}

${ }^{1}$ In $M M 2$, we quote from Noddings (2010) who states: "successful practice in caring depends in the caring relation between master-carer and the one learning to care. One must learn (consciously or unconsciously) what it means to be cared for before one can learn to care for others" (147). We also explore the notion of "master drummers" $(113,216,221)$, as they are typically referred to in Western 
Africa. Additionally, when we refer to "master teachers" (9), we mean a teacher who possesses expertise. And we mention that Count Basie was a "master" jazz musician (276). The above are the only references to the word "master" in MM2.

Elliott, David J., and Marissa Silverman. 2017. On the "truthiness" of Remixing the Classroom. Action, Criticism, and Theory for Music Education 16 (1): 124-67. doi:10.22176/act16.1.124 